\title{
First Record of Chrysomya rufifacies (Macquart) (Diptera, Calliphoridae) in Southeastern Brazil
}

\author{
Antonia de Castro Ribeiro ${ }^{1}$, Debora Cardoso ${ }^{\bowtie}$, Cláudia Soares dos Santos Lessa ${ }^{1}$, \\ Gonzalo Efrain Moya-Borja ${ }^{3}$ \& Valéria Magalhães Aguiar1
}

1. Universidade Federal do Estado do Rio de Janeiro, e-mail: antoniaribeiro.o9@gmail.com, lessaclss@gmail.com, valerialed@yahoo.com.br. 2. Universidade Estadual do Sudoeste da Bahia - Campus Itapetinga, e-mail: dcardoso_rj@ hotmail.com (Autor para correspondência ${ }^{\bowtie}$ ). 3. Universidade Federal Rural do Rio de Janeiro, e-mail: gemoya@ufrrj.br.

\section{EntomoBrasilis 6 (3): 245-247 (2013)}

Abstract. The present note reports the first record of Chrysomya rufifacies (Macquart) in Southeastern Brazil, in the municipality of Seropédica, Rio de Janeiro. The collecting was conducted with Diptera traps using fresh fish as bait.

Keywords: Biodiversity; Blowfly; Exotic specie.

\section{Primeiro Registro de Chrysomya rufifacies (Macquart) (Diptera, Calliphoridae) no Sudeste do Brasil}

Resumo. A presente nota relata o primeiro registro da espécie Chrysomya rufifacies (Macquart), no Sudeste do Brasil, no Município de Seropédica, Rio de Janeiro. As coletas foram realizadas com auxílio de armadilhas para dípteros e a isca utilizada foi peixe fresco.

Palavras-Chave: Biodiversidade; Espécie exótica; Mosca varejeira.

IL n the 1970s, three species of Chrysomya (Calliphoridae) were introduced to Brazil: Chrysomya megacephala (Fabricius), Chrysomya albiceps (Wiedemann) and Chrysomya putoria (Wiedemann). After their introduction, these species rapidly dispersed throughout the country (GUIMARÃEs et al. 1978). This genus has medical and veterinary importance, may cause myiasis (Guimarães \& PAPAVERO 1999; Ferraz et al. 2011), and disseminates pathogens (Ribeiro et al. 2011). They are also listed as being relevant in forensic entomology by assisting in post-mortem interval determination (OlIVEIRA-CosTa 2007; BARRos-SouZA 2012). Furthermore, they play an important ecological role, due to high predatory capacity (BAUMGaRTNER 1993) this genus has been changing the frequency and abundance of populations of local fauna (LEANDRo \& D'AlmEIDA 2005).

Chrysomy a rufifacies (Macquart) is a native species of Australasia and Pacific regions (WEELS \& GREENBERG 1992). The first record of this species in the New World was in Costa Rica (JIRON 1979). The distribution of $C$. rufifacies includes other New World countries, such as Canada (Rosati \& VANLAERHoven 2007), United States of America (Shahid et al. 2000), Mexico (VALdes-PEREZGASGa et al. 2010), Panama (Bermudez et al. 2007), Colombia (BArreto et al. 2002) and Argentina (MARILUIS \& SchNACK 1989). In Brazil, this species had been only collected in an area of "Cerrado" (savannalike vegetation) in the municipality of Caxias in state of Maranhão (Silva et al. 2012).

Four female $C$. rufifacies were collected in the municipality of Seropédica, Rio de Janeiro ( $\left.22^{\circ} 45^{\prime} 48^{\prime \prime} \mathrm{S} 43^{\circ} 41^{\prime} 23^{\prime \prime} \mathrm{W}\right)$, two were collected in December 2011 and two were collected in February 2012. For collection, the Diptera traps described by MelLo et al. (2007) were used with fresh fish (sardine) as bait and exposed for a period of 30 hours approximately 1.5 meters above the ground. The captured insects were sacrificed using ether, stored in polyethylene bags and then placed in a freezer at $-10^{\circ} \mathrm{C}$. During the sorting process, the insects of the family Calliphoridae were transferred to glass vials containing $70 \%$ alcohol. The material was stored and analyzed at the Laboratory of Diptera Studies in the Department of Microbiology and Parasitology, Universidade Federal do Estado do Rio de Janeiro - UNIRIO. After the insects were dried with incident light, they were pinned and identified following the taxonomic keys of GUIMARÃES \& PAPAVERO (1999), Amat et al. (2008), Амat (2009), Whitworth (2010) and Silva et al. (2012). Two female were deposited in the Entomological Collection of Laboratory of Diptera Studies - UNIRIO and two female were deposited in the Entomological Collection of Nacional Museum - UFRJ, both located in Rio de Janeiro, state of Rio de Janeiro.

In the specimens collected, all the morphological traits were shown used to identify this species, as can be observed in the photomicrographs (Figure $1 \mathrm{~A}, 1 \mathrm{~B}, 1 \mathrm{C}$ ). The characteristics that were shown and that identify this species are: orange gena (Figure 1A) (Guimarães \& PAPAVERO 1999), strong proepisternal setae (Figure 1A, 1C) (Guimarães \& Papavero 1999; Amat et al. 2008; AMAT 2009; Whitworth 2010; Silva et al. 2012), and in the females, tergite 5 a dorsal cleft in the posterior margin (Figure 1B) (Амат et al. 2008; Амat 2009; Whitworth 2010; Silva et al. 2012).

This scientific note is the first record of C. rufifacies in the southeastern region of Brazil. Considering that this species occupies the same niche as other Diptera of the Calliphoridae family, there will probably be new ecological interactions with the existing community, transforming it, because the interspecific interactions are important ecological mechanisms that can influence the behavior dynamic of the species. WELLS \& GREENBERG (1992) suggested the decline of the $C$. macellaria population in the presence of $C$. rufifacies.

Agências de Financiamento: UNIRIO, CNPq, FAPERJ, FINEP, UFRRJ e UESB. 
This record can be considered as a warning to entomologists and health authorities to pay attention to new field collections and
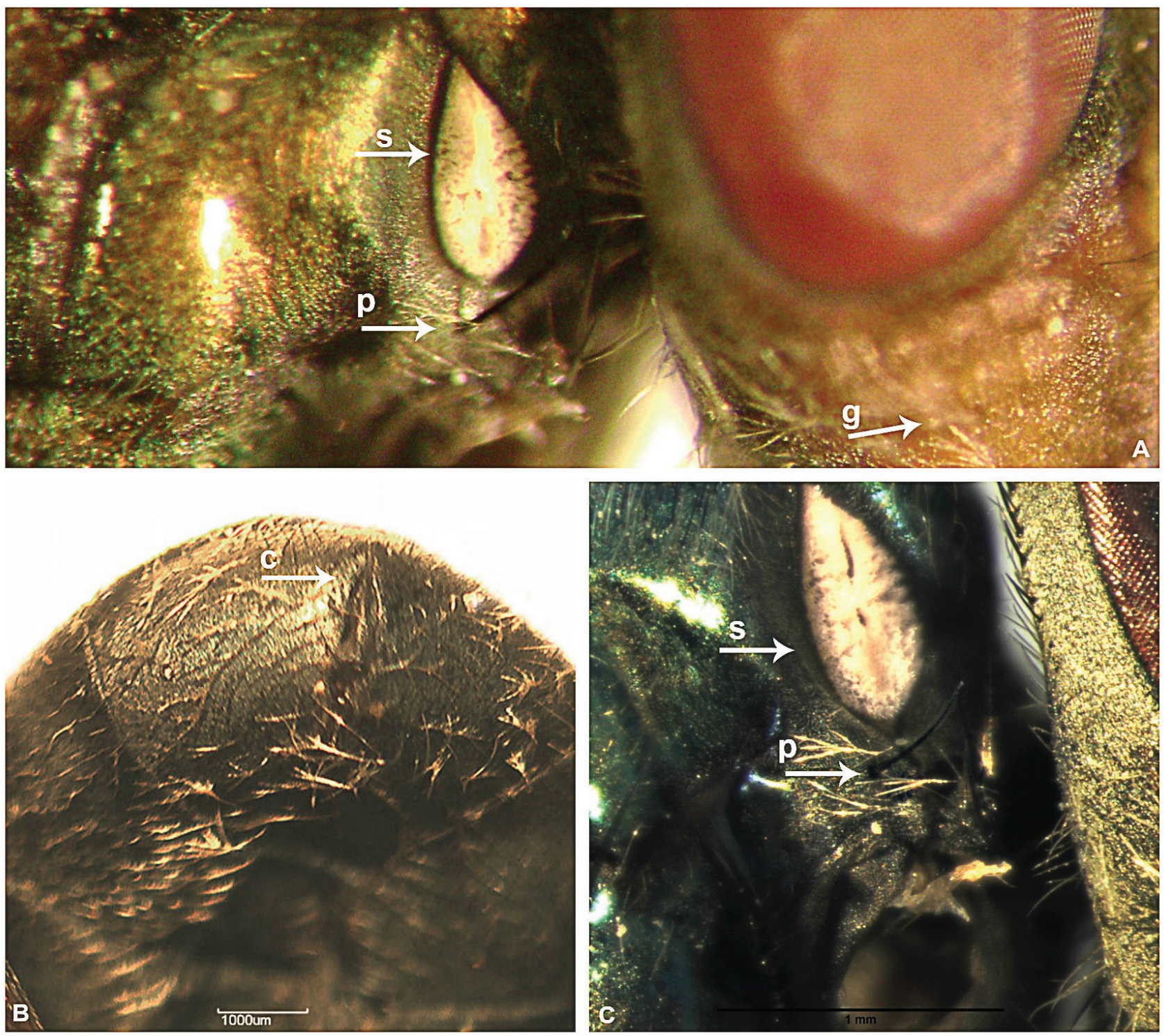

Figure 1. Chrysomya rufifacies (Macquart), A - orange gena (g), proepisternal setae (p) and anterior thoracic spiracle pale (s); B - female fifth tergite with a cleft (c) in the posterior margin, ventral view; C - proepisternal setae (p) and anterior thoracic spiracle pale (s), lateral view of thorax. Picture: A.C. Ribeiro

\section{ACKNOWLEDGEMENTS}

The authors would like to thank the LABAN - Laboratório de Biossistemática de Anfíbios (UNIRIO) and M.Sc. Barbara Proença (Museu Nacional - UFRJ) for their support by the pictures. Conselho Nacional de Desenvolvimento Científico e Tecnológico - CNPq, Fundação de Amparo à Pesquisa do Estado do Rio de Janeiro - FAPERJ, Financiadora de Estudos e Projetos - FINEP, Universidade Federal do Estado do Rio de Janeiro UNIRIO, Universidade Estadual do Sudoeste da Bahia - UESB, Universidade Federal Rural do Rio de Janeiro - UFRRJ for their financial support.

\section{REFERENCES}

Amat, E., 2009. Contribuciónal conocimiento delas Chrysomyinae y Toxotarsinae (Diptera: Calliphoridae) de Colombia. Revista Mexicana de Biodiversidad, 80: 693-708.

Amat, E., M.C. Vélez \& M. Wolff, 2008. Clave ilustrada para La identificación de los géneros y las especies de califóridos (Diptera:Calliphoridae) de Colombia. Caldasia, 30: 231-244. Barreto, M., M.E. Burbano\&P. Barreto, 2002. Flies (Calliphoridae, Muscidae) and Beetles (Silphidae) from Human Cadavers in Cali, Colombia. Memórias do Instituto Oswaldo Cruz, 97:
$137-138$

Barros-Souza, A.S., R.L. Ferreira-Keppler \& D.B. Agra, 2012. Development Period of Forensic Importance Calliphoridae (Diptera: Brachycera) in Urban Area Under Natural Conditions in Manaus, Amazonas, Brazil. EntomoBrasilis, 5: 99-105.

Baumgartner, D., 1993. Rewiew of Chrysomya rufifacies (Diptera: Calliphoridae). Journal of Medical Entomology, 30: 338-352.

Bermúdez, S.E., J.D. Espinosa, A.B. Cielo, F. Clavel, J. Subía, S. Barrios \& E. Medianero, 2007. Incidence of myiasis in Panama during the eradication of Cochliomyia hominivorax (Coquerel 1858, Diptera: Calliphoridae) (2002-2005). Memórias do Instituto Oswaldo Cruz, 102: 675-679.

Ferraz, A.C.P., V.R.G. Almeida, D.M. Jesus, G.N. Rotatori, R. Nunes, B. Proença, V.M. Aguiar-Coelho \& C.S.S. Lessa, 2011. Epidemiological Study of Myiases in the Hospital do Andaraí, Rio de Janeiro, Including Reference to an Exotic Etiological Agent. Neotropical Entomology, 40: 393-397.

Guimarães, J.H. \& N. Papavero, 1999. Myiasis in man and animals in the neotropical region. São Paulo: Bibliographic Database. Editora Plêiade/Fapesp. 308 p.

Guimarães, J.H., A.P. Prado \& A.X. Linhares, 1978. Three newly introduced blowfly species in Southern Brazil (Diptera, 
Calliphoridae). Revista Brasileira de Entomologia, 22: 5360.

Jiron, L.F. 1979. On the calliphorid flies of Costa Rica (Diptera: Cyclorrhapha). Brenesia, 16: 221-223.

Leandro, M.J.F. \& J.M. D’Almeida, 2005. Levantamento de Calliphoridae, Fanniidae, Muscidae e Sarcophagidae em um fragmento de mata na Ilha do Governador, Rio de Janeiro, Brasil. Iheringia Série Zoologia, 95: 377-381.

Mariluis, J.C. \& J.A. Schnack, 1989. Ecology of the blow flies of an eusynanthropic habitat near Buenos Aires (Diptera, Calliphoridae). Eos-Revista Espanola de Entomologia, 65: 93-101.

Mello, R.S., M.M.C. Queiroz \& V.M. Aguiar-Coelho, 2007. Population fluctuations of calliphorid species (Diptera,Calliphoridae) in the Biological Reserve of Tinguá, state of Rio de Janeiro, Brazil. Iheringia Série Zoologia, 97: 1-5.

Oliveira-Costa, J., 2007. Entomologia Forense: quando os insetos são vestígios. Campinas: Millennium. 425 p.

Ribeiro, M.J.R., S.M.F. Dias, E. Teshima \& A.R. Barboni, 2011. Insalubridade ambiental e aspectos ambientais associados a patógenos intestinais isolados de dípteros. Revista Engenharia Sanitária e Ambiental, 16: 83-90.

Rosati, J.Y. \& B. Vanlaerhoven, 2007. New record of Chrysomya rufifacies (Diptera: Calliphoridae) in Canada: predicted range expansion and potential effects on native species. Canadian Entomology, 139: 670-677.
Shahid, S.A., R.D. Hall, N.H. Haskell \& R.W. Merritt, 2000. Chrysomya rufifacies (Macquart) (Diptera: Calliphoridae) established in the vicinity of Knoxville, Tennessee, USA. Journal of Forensic Scienci, 45: 896-897.

Silva, J.O.A., F.S. Carvalho-Filho, M.C. Esposito \& G.A. Reis, 2012. First record of Chrysomya rufifacies (Macquart) (Diptera, Calliphoridae) from Brazil. Revista Brasileira de Entomologia, 56: 115-118.

Valdes-Perezgasga, M.T., F.J. Sanchez-Ramos, O. GarciaMartinez \& G.S. Anderson, 2010. Arthropods of Forensic Importance on Pig Carrion in the Coahuilan Semi desert, Mexico. Journal of Forensic Scienci, 55: 1098-1101.

Wells, J.D. \& B. Greemberg, 1992. Interaction between Chrysomya rufifacies and Cochliomyia macellaria (Diptera: Calliphoridae): the possible consequences of an invasion. Bulletin of Entomological Research, 82: 133-137.

Whitworth, T., 2010. Keys to the genera and species of blow flies (Diptera: Calliphoridae) of the West Indies and description of a new species of Lucilia Robineau-Desvoidy. Zootaxa, 2663: 1-35.

\section{Recebido em: 04/02/2013}

Aceito em: 21/o7/2013

\section{Como citar este artigo:}

Ribeiro, A.C., D. Cardoso, C.S. Lessa, G.E. Moya-Borja \& V.M. Aguiar, 2013. First Record of Chrysomya rufifacies (Macquart) (Diptera, Calliphoridae) in Southeastern Brazil. EntomoBrasilis, 6(3): 245-247.

Acessível em: http://www.periodico.ebras.bio.br/ojs/index.php/ebras/article/view/321. doi:10.12741/ebrasilis.v6i3.321
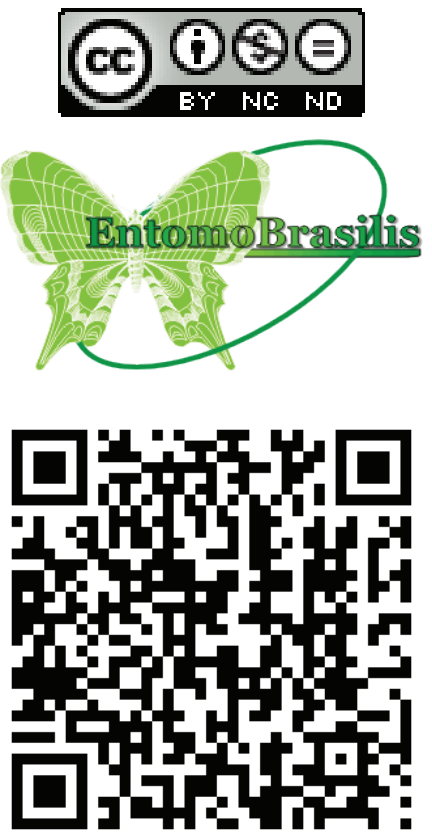